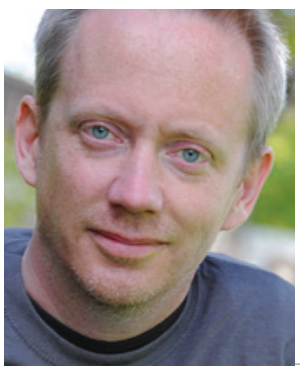

\title{
Udødeligheten varer ikke så lenge
}

\author{
Vissheten om at vi vil leve i all
} evighet, svinner sakte hen idet vi vokser opp. Følelsen av uendelighet sitter ofte noe lenger. Når hver måned føles som en evighet og selv mennesker på 30 år er eldgamle, er gjerne døden noe uhyre fjernt. Men snart, så altfor snart, forsvinner også denne følelsen av evig tid.

Så da sitter vi der, som så uendelig mange før oss, med vissheten om alt er begrenset. Allerede for tusener av år siden, i den eldste fortellingen vi noensinne har bevart, protesterte helten Gilgamesh mot denne gudegitte orden: «Jeg vil ikke dø! !» Til ingen nytte. Hans lange søken etter udødelighet leder ingensteds hen. Men er det slik også med oss?

Jeg har nylig gransket troen på fysisk udødelighet. Jeg har lest de mest obskure tekster om hvordan mange er overbevist om at den ene eller den andre har klart å oppnå den evigheten alle vi andre bare kan drømme om. Men ingen av disse beretningene kan bevises. Ingenting i disse gamle tekstene synes å føre oss nærmere målet. Eller, nesten ingen. For her kommer legevitenskapen inn.

De fleste udødelighetsmytene handler om gudenes fantastiske inngripen. Men når medisinen er involvert, er det ikke lenger like mirakuløst. I mytene bare utvides den medisinske evnen til å utsette døden. Å gi oss litt mer tid er essensen i så mye av legevitenskapen. Så hvorfor ikke bare utvide denne mertiden i all evighet. Som Asklepios, den legendariske legen fra gresk oldtid som kunne kurere hva som helst. Han gjenopp- vekket til og med nylig avdøde. Slik kunne døden utsettes igjen og igjen i evig tid.

Gudene var ikke så altfor begeistret for Asklepios' udødelighetsfors $\varnothing$ k og drepte ham med en lynkile. Men likevel: de lot ham gjenoppstå etterpå, fysisk udødelig og guddommelig. Og som medisinens skytsgud viste han stadig veien.

Om gudene ikke likte at Asklepios på egenhånd overskred dødens grenser, grep de likevel stadig inn og gjorde den ene eller andre favoritten fysisk udødelig. Alle disse fantastiske beretningene har samtidig alle det til felles at det handler om mennesker som ikke lenger er blant oss. Det er ikke slik at Ganymedes eller Alkmene lenger er å finne i en eller annen gresk provinsby. Samtidig som de ble gjort fysisk udødelige ble de med kropp og sjel tatt opp til himmelen - akkurat som Jesus senere. Andre udødeliggjorte lever i all evighet ved verdens ende, i havet eller under jordoverflaten. Hvis vi skal tro de gamle skriftene.

De gamle gudene valgte likevel bare å gjøre noen få fysisk udødelige. Med kristendommen ble dette plutselig en mulighet for alle - hvis man bare trodde at dette hadde skjedd med Jesus. Men kristendommen utsatte samtidig sitt løfte til historiens slutt. Her og nå ble ingen lenger udødelige. Og for å gjøre Jesus mer unik. fornektet de kristne også at det hadde skjedd med noen andre før.

Da det ble færre av de udødelige, ble det desto flere mirakler. Som en forsmak på den udødeligheten vi er lovet. Gud og helgenene reddet oss fra sykdommene og lidelsene. Be og du vil bli hørt.

For oss som er på utsiden av både gudenes og medisinens verden, kan det noen ganger være vanskelig å se for- skjellen. Det som legene klarer å redde oss fra i dag, står ofte ikke tilbake for fortidens mest vidunderlige, guddommelige mirakler. Like så uforståelig. Like så mytisk. Og mens vi stadig venter på at gudene skal komme tilbake og gjøre noe med døden en gang for alle, er det medisinen som stadig har flyttet på dødens grenser. Det ene etter det andre som før betydde den visse $d ø d$, er blitt svekket, redusert eller fullstendig nedkjempet.

I dag er det også mot legevitenskapen, ikke mot gudene, de fleste ser når de tenker på muligheten for å gjenopprette den udødeligheten vi en gang trodde vi hadde da vi var små. Vi håper som Dr. Frankenstein i Mary Shelleys roman fra 1818: «Om jeg kunne fordrive all sykdom fra den menneskelige natur og gjøre mennesket usårbart for alt unntatt voldsom $\mathrm{d} \varnothing \mathrm{d} ! »$

Mennesker lar seg fryse ned i påvente av det endelige medisinske gjennombruddet. Om du bare har tre millioner dollar disponibelt, lover organisasjonen 2045 Initiative at du er på sikker vei mot udødeligheten. Vi tror og håper at legevitenskapen stadig vil kunne reparere oss ytterligere. Erstatte våre utslitte kroppsdeler, fikse genene våre, reversere aldringsprosessen.

Så skal vi vende tilbake til vår opprinnelige evige tilstand? Tilbake til da døden ikke var noe som bekymret oss. Tilbake til uendeligheten.

Men vi vil fremdeles bli sittende igjen med det dilemmaet at så mange av oss ikke aner hva vi skal finne på en regntung søndagsettermiddag.

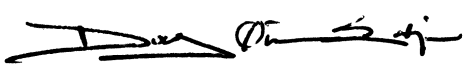

